\title{
A multivariate approach to the association pattern of reciprocal translocations induced by chemicals and ionizing radiation in mouse germ cells
}

\author{
J.C. De Lucal, E. Ortiz Jaureguizar ${ }^{2}$ and F.N. Dulout ${ }^{1}$
}

\begin{abstract}
The degree of similarity between chemical and physical agents in their capacity to induce reciprocal translocations was analyzed by means of multivariate analysis techniques. The effect of three different doses of gamma rays, four doses of X-rays and different doses of adriamycin, mitomycin C, thio-tepa and bleomycin was analyzed. Data were arranged in a basic matrix by two methods: cluster analysis and ordination. Two main groups were found, one including doses of 9 and $10 \mathrm{~Gy}$ and the other including the remaining lower doses of ionizing radiation and the other chemicals. Various subgroups were found within the second group. Accordingly, using presence/absence data there was not a specific pattern of chromosomal damage induction for physical and chemical agents. The increase in the frequencies of reciprocal translocation observed with 9 and $10 \mathrm{~Gy}$ was due to an increase in the kind of multivalent configurations. This variability could be dose dependent. Likewise, the similarity observed in the second group between the chemicals and the lower doses of ionizing radiation could also be dose dependent.
\end{abstract}

\section{INTRODUCTION}

Cells are constantly exposed to exogenous and endogenous agents which may damage the genetic material, being the DNA molecule the main target. Physical and chemical agents can interact with this molecule in different ways through the induction of DNA double- and singlestrand break, cross-links and base damage. In all cases the primary lesions must be amplified to be detected as chromosomal aberrations. On the other hand, ionizing radiations can interact with macromolecules or cellular structures in two ways: first, when the damage is directly induced in the macromolecules by ionized particles, and second, when the damage is induced by free radicals produced by the ionization of cellular water. In a similar way, some chemicals like adriamycin (ADR), mitomycin C (MMC) and bleomycin (BLM) can interact with DNA in different ways such as intercalation, DNA adduct formation and free radical induction, respectively (Pigram et al., 1972; Povirk and Austin, 1991; Sanderson and Shield 1996). Information obtained from analysis of reciprocal translocations induced by physical and chemical agents in mammalian germ cells includes multivalent configuration types and frequencies. The data obtained provide information about the effects of the agent tested as well as dose-response relationships. However, analysis of the frequencies of multivalent configurations induced by different treatments helped to develop two questions: 1) Is there a specific pattern of chromosomal damage induction for each agent? 2) Is it possible to compare the effects of dif- ferent agents in order to establish similarities and differences? Attempts to answer this last question have included comparing the effect of chemicals and ionizing radiation (e.g., van Buul and Gouzdwaard, 1980) from a subjective point of view, without any statistical or mathematical evaluation. In order to accurately determine the degree of similarity or difference between the effects of chemicals and ionizing radiations in relation to the induction of reciprocal translocations in germ cells, multivariate analysis methods were used. Originally developed for systematic biology (Rohlf, 1963; Sneath, 1964; Crovello, 1968; Crisci and López Armengol, 1983), these methods have been recently employed to solve similar problems in other disciplines (e.g., Sneath, 1966; Williams et al., 1966; Gillie and Peto, 1969; Wishart and Leach, 1970; Winkler and Sokal, 1987; Pascual and Ortiz Jaureguizar, 1990).

\section{MATERIAL AND METHODS}

\section{Operational taxonomic unit (OTU) selection}

Relationships between three gamma ray (GR) doses $(1,5$, and $9 \mathrm{~Gy})$ as well as different doses of the chemicals ADR, MMC, BLM and thio-tepa (TT) were analyzed. Data were obtained from experiments carried out in male BALB/c mice (De Luca et al., 1988, 1990a,b). In addition, data obtained from van Buul and Léonard (1980) about the effect of $0.25,0.50,0.75,1$, and $10 \mathrm{~Gy}$ of X-rays (XR) were included in the analysis. Table I summarizes the different treatments considered. Some of the 14 treatments

${ }^{I}$ Centro de Investigaciones en Genética Básica y Aplicada (CIGEBA). Facultad de Ciencias Veterinarias, Avenida 60 y 118, s/n, CC 296, 1900 La Plata, Argentina. Send correspondence to J.C.L. E-mail: jdeluca@fcv.medvet.unlp.edu.ar ${ }^{2}$ Laboratorio de Sistemática y Biología Evolutiva (LASBE), Facultad de Ciencias Naturales y Museo. Paseo del Bosque s/n, 1900 La Plata, Argentina.E-mail:eortiz@museo.fcnym.unlp.edu.ar 
induced the same types of reciprocal translocations (i.e., ADR5-MMC-0.75-1 Gy; TT-BLM20-BLM40; 5 GyBLM60; see Tables III and IV), although frequencies were different (van Buul and Léonard, 1980; De Luca et al., $1988,1990 a, b)$. Data were not clustered since this procedure did not modify the results obtained.

\section{Data accumulation}

The data considered include 10 "characters", i.e., reciprocal translocations, induced in stem cell spermatogonia and scored as multivalent configurations in diakinesis-metaphase I. All characters were qualitative and scored as presence/absence. Table II summarizes the different configurations considered and their corresponding codifications.

Table I - Experimental protocol employed to compare reciprocal translocation type induced by the different treatments.

\begin{tabular}{|lcc|}
\hline Agent & Dose & Number of mice studied \\
\hline ADR & $5 \mathrm{mg} / \mathrm{kg}$ & 11 \\
ADR & $10 \mathrm{mg} / \mathrm{kg}$ & 4 \\
MMC & $2 \mathrm{mg} / \mathrm{kg}$ & 8 \\
BLM & $20 \mathrm{mg} / \mathrm{kg}$ & 6 \\
BLM & $40 \mathrm{mg} / \mathrm{kg}$ & 6 \\
BLM & $60 \mathrm{mg} / \mathrm{kg}$ & 6 \\
TT & $0.2 \mathrm{mg} / \mathrm{kg}$ & 7 \\
GR & $1 \mathrm{~Gy}$ & 4 \\
GR & $5 \mathrm{~Gy}$ & 10 \\
GR & $9 \mathrm{~Gy}$ & 11 \\
XR & $0.25 \mathrm{~Gy}$ & 10 \\
XR & $0.50 \mathrm{~Gy}$ & 18 \\
$\mathrm{XR}^{*}$ & $0.75 \mathrm{~Gy}$ & 10 \\
$\mathrm{XR}^{*}$ & $10 \mathrm{~Gy}$ & 9 \\
\hline
\end{tabular}

ADR: Adriamycin; MMC: mitomycin C; BLM: bleomycin; TT: thio-tepa; GR: gamma rays; XR: X-rays. *Data from van Buul and Léonard (1980).

Table II - Codification of the multivalent configurations employed as "characters".

\begin{tabular}{|c|c|}
\hline $\begin{array}{l}\text { Multivalent configuration } \\
\text { ("characters") }\end{array}$ & Codification \\
\hline $18 \mathrm{II}+1 \mathrm{CIV}$ & Present (1) : Absent (0) \\
\hline $18 \mathrm{II}+1 \mathrm{RIV}$ & Present (1): Absent (0) \\
\hline $18 \mathrm{II}+\mathrm{CIII}+1 \mathrm{I}^{*}$ & Present (1): Absent (0) \\
\hline $17 \mathrm{II}+1 \mathrm{CVI}$ & Present (1) : Absent (0) \\
\hline 16II + 1 CVIII & Present (1) : Absent (0) \\
\hline $16 \mathrm{II}+1 \mathrm{CIV}+1 \mathrm{RIV}$ & Present (1): Absent (0) \\
\hline $16 \mathrm{II}+2 \mathrm{CIV}$ & Present (1): Absent (0) \\
\hline $16 \mathrm{II}+2 \mathrm{RIV}$ & Present (1): Absent (0) \\
\hline $15 \mathrm{II}+1 \mathrm{CIV}+1 \mathrm{CVI}$ & Present (1): Absent (0) \\
\hline $15 \mathrm{II}+1 \mathrm{CIV}+1 \mathrm{RVI}$ & Present (1) : Absent (0) \\
\hline
\end{tabular}

I: Univalent; II: bivalent configuration; III: trivalent configuration; IV: tetravalent configuration; VI: hexavalent configuration; VIII: octovalent configuration; C: multivalent chain; R: multivalent ring. *Data from van Buul and Léonard (1980).
Data processing

Data were arranged in a basic data matrix (BDM) (Table III) of 14 OTUs by 10 reciprocal translocation types. BDM was analyzed by means of two methods: cluster analysis and ordination. Computer analysis was done on a Pentium-II ${ }^{\mathrm{TM}}$ IBM-compatible PC at the LASBE (Laboratorio de Sistematica y Biologia Evolutiva, Museo de La Plata) by means of the NTSYS-pc 2.0 library of numerical taxonomical programs developed by Rohlf (1997). Details about methods and computational procedures can be found in Sneath and Sokal (1973) and Rohlf (1997).

\section{Cluster analysis}

BDM was transformed into a similarity association matrix (SAM) among OTUs using the Jaccard coefficient (Sneath and Sokal, 1973). SAM served as input in the calculation of a phenogram by the unweighted pair-group method using arithmetic averages (UPGMA) (Sokal and Michener, 1958). Cophenetic correlations between the phenogram and SAM input were computed using the cophenetic correlation coefficient (CCC) (Sokal and Rohlf, 1962). If more than one phenogram was obtained, a consensus tree was performed to summarize the results. A consensus tree represents the consensus topology (subset of relationship) of two or more trees, and was obtained by the majority rule consensus method (Margus and McMorris, 1981). The consensus index CIc (Rohlf, 1982) was employed as a measure of the similarity of the original trees.

\section{Ordination}

The OTU x OTU SAM obtained in 3.1. was transformed into a scalar product form so that its eigenvalues and eigenvectors could be computed, resulting in a principal coordinate analysis (Gower, 1966). The results of the principal coordinate analysis were used as an initial configuration matrix to perform a nonmetric multidimensional scaling analysis (Kruskal, 1964a,b). This technique represents dissimilarities among any objects or variables by any point in $\mathrm{K}$-dimensional space so that the interpoint distances in the K-dimensional space correspond as much as possible to the observed distances between the objects. Distances were fitted in K-dimensional space to a monotone function of the original distances with a coefficient called "stress" (Kruskal, 1964a,b). This author suggests verbal evaluations for various levels of stress:

$\begin{array}{cc}\text { Stress } & \text { Goodness of fit } \\ 0.40 & \text { Poor } \\ 0.20 & \text { Fair } \\ 0.10 & \text { Good } \\ 0.05 & \text { Excellent } \\ 0.00 & \text { "Perfect" }\end{array}$


Table III - Basic matrix data employed for the multivariate analysis (BMD).

\begin{tabular}{|c|c|c|c|c|c|c|c|c|c|c|}
\hline \multirow[b]{2}{*}{ OTU } & \multicolumn{10}{|c|}{ Multivalent configurations (“character") } \\
\hline & $\begin{array}{l}18 \mathrm{II}+ \\
1 \mathrm{CIV}\end{array}$ & $\begin{array}{l}18 \mathrm{II}+ \\
1 \mathrm{RIV}\end{array}$ & $\begin{array}{c}15 \mathrm{II}+ \\
1 \mathrm{CIV}+1 \mathrm{CVI}\end{array}$ & $\begin{array}{c}15 \mathrm{II}+ \\
1 \mathrm{CIV}+1 \mathrm{RVI}\end{array}$ & $\begin{array}{l}17 \mathrm{II}+ \\
1 \mathrm{CVI}\end{array}$ & $\begin{array}{l}16 \mathrm{II}+ \\
2 \mathrm{CIV}\end{array}$ & $\begin{array}{l}16 \mathrm{II}+ \\
1 \mathrm{CVIII}\end{array}$ & $\begin{array}{l}16 \mathrm{II}+ \\
2 \mathrm{RIV}\end{array}$ & $\begin{array}{c}18 \mathrm{II}+ \\
\mathrm{CIII}+1 \mathrm{I}\end{array}$ & $\begin{array}{l}17 \mathrm{II}+ \\
1 \mathrm{RVI}\end{array}$ \\
\hline ADR5 & 1 & 1 & 0 & 0 & 0 & 0 & 0 & 0 & 0 & 0 \\
\hline MMC & 1 & 1 & 0 & 0 & 0 & 0 & 0 & 0 & 0 & 0 \\
\hline $0.75 \mathrm{~Gy}$ & 1 & 1 & 0 & 0 & 0 & 0 & 0 & 0 & 0 & 0 \\
\hline $1 \mathrm{~Gy}$ & 1 & 1 & 0 & 0 & 0 & 0 & 0 & 0 & 0 & 0 \\
\hline ADR10 & 1 & 1 & 0 & 0 & 1 & 0 & 0 & 0 & 0 & 0 \\
\hline $5 \mathrm{~Gy}$ & 1 & 1 & 0 & 0 & 0 & 0 & 1 & 0 & 0 & 0 \\
\hline BLM60 & 1 & 1 & 0 & 0 & 0 & 0 & 1 & 0 & 0 & 0 \\
\hline $9 \mathrm{~Gy}$ & 1 & 1 & 1 & 1 & 1 & 1 & 0 & 1 & 0 & 0 \\
\hline $0.25 \mathrm{~Gy}$ & 1 & 1 & 0 & 0 & 0 & 0 & 0 & 0 & 1 & 0 \\
\hline $0.50 \mathrm{~Gy}$ & 1 & 1 & 0 & 0 & 0 & 0 & 0 & 0 & 1 & 0 \\
\hline $10 \mathrm{~Gy}$ & 1 & 1 & 0 & 0 & 1 & 0 & 0 & 1 & 1 & 1 \\
\hline TT & 1 & 0 & 0 & 0 & 0 & 0 & 0 & 0 & 0 & 0 \\
\hline BLM20 & 1 & 0 & 0 & 0 & 0 & 0 & 0 & 0 & 0 & 0 \\
\hline BLM40 & 1 & 0 & 0 & 0 & 0 & 0 & 0 & 0 & 0 & 0 \\
\hline
\end{tabular}

OTU, Operational taxonomic units. For other abbreviations see Tables I and II.

\section{RESULTS}

\section{Cluster analysis}

Using UPGMA, we obtained four phenograms (CCC $=0.93885)$ of association among OTUs (Figure 1A-D). The consensus tree (Figure 2) showed seven common groups: a) formed by ADR5, MMC, $1 \mathrm{~Gy}, 0.75 \mathrm{~Gy}$, ADR10, 5 Gy, BLM60, 0.25 Gy, 0.50 Gy, TT, BLM40 and BLM20; b) formed by ADR5, MMC, $1 \mathrm{~Gy}, 0.75 \mathrm{~Gy}, \mathrm{ADR} 10,5 \mathrm{~Gy}$, BLM60, 0.25 Gy and $0.50 \mathrm{~Gy}$; c) formed by ADR5, MMC, $1 \mathrm{~Gy}$ and $0.75 \mathrm{~Gy}$; d) formed by $5 \mathrm{~Gy}$ and BLM60, e) formed by $0.25 \mathrm{~Gy}$ and $0.50 \mathrm{~Gy} ; \mathrm{f}$ ) formed by TT, BLM40 and BLM20, and g) formed by $9 \mathrm{~Gy}$ and $10 \mathrm{~Gy}$. The CIc was 0.58333 . Differences between the four phenograms consisted of minor variations in the relationships (transpositions) between members of group $b$.

\section{Ordination}

In the bidimensional graphic (Figure 3) three treatment groups can be recognized $(56.88 \%$ of the variance): a) formed by TT, BLM20, BLM40; b) formed by BLM60, $5 \mathrm{~Gy}, \mathrm{ADR} 5, \mathrm{MMC}, 1 \mathrm{~Gy}, 0.75 \mathrm{~Gy}, 0.25 \mathrm{~Gy}, 0.50 \mathrm{~Gy}$ and ADR 10, and c) formed by 9 Gy and $10 \mathrm{~Gy}$. The final "stress" was 0.03893 .

\section{DISCUSSION}

The results obtained showed two main groups: one including treatments with 9 Gy of GR and 10 Gy of XR, and the other including all the chemical compounds and the remainder doses of GR and XR (Figures 1, 2 and 3). Accordingly, using presence/absence data there was not a specific pattern of chromosomal damage induction for physical and chemical agents. In effect, both kinds of agents were grouped together, with the only exception of the greatest doses of XR and GR, that comprise a separate group not only in comparison with the chemicals but also with the lower doses of GR and XR.

The association of $9 \mathrm{~Gy}$ of GR and $10 \mathrm{~Gy}$ of $\mathrm{XR}$ is expected since GR and XR induce similar kinds of reciprocal translocations. This agrees with the fact that these doses correspond to the descending part of the dose-response curve for induction of reciprocal translocations by single doses of ionizing radiation (Léonard and Deknudt, 1969). Table III shows that 9 Gy of GR and 10 Gy of XR induced a similar kind of reciprocal translocations and a higher variability of reciprocal translocations than drugs and the remaining doses of radiation. On the other hand, Table IV shows that these doses increased the frequency of reciprocal translocations (the frequencies of 5 and 9 Gy of GR could be overestimated by the lower number of cells scored).

Some increase in the frequency of reciprocal translocations at high doses of ionizing radiation was observed in the guinea pig (Lyon and Cox, 1975), the mouse (van Buul and Goudzwaard, 1986) and the rhesus monkey (van Buul, 1991). On the other hand, all results so far reported on high exposure indicate some induction of translocation (van Buul, 1991).

Leenhouts and Chadwick (1981) and van Buul and Seelen (1991) have postulated three main parameters of the stem cell spermatogonial population that affect the level of induced translocations: 1) the proportion of sensitive and resistant cells; 2) the ratio of the probabilities that a basic lesion in the DNA leads to cell killing or translocation formation, and 3) the proliferation-differentiation pattern of surviving spermatogonial stem cells after irradiation. Significant increase of intra- as well as inter-in- 

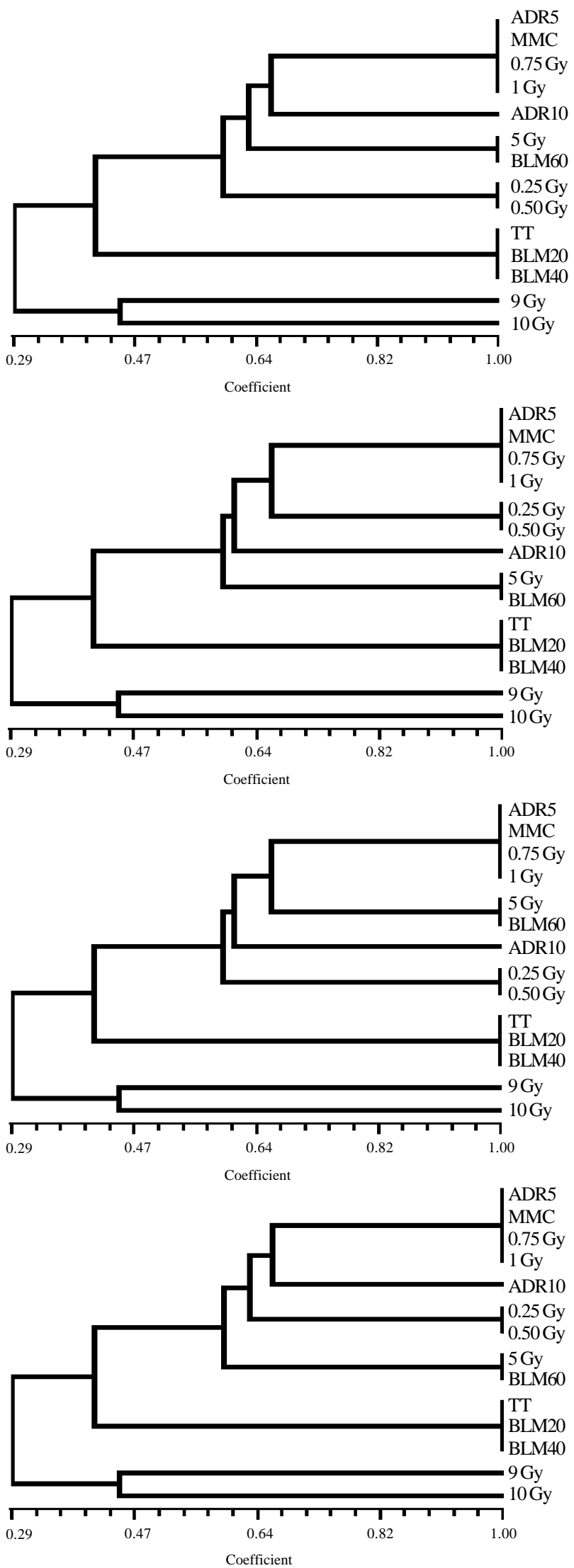

Figure 1 - A-D - Phenogram (UPGMA) of association (Jaccard coefficient) obtained from the 14 treatments. CCC was 0.93885 . See references on Material and Methods, and Table I. dividual variability is produced by high degrees of cell killing due to the increase in the effect of clonal proliferation of the relatively few surviving stem cells (Léonard and Deknudt, 1969; van Buul and Léonard, 1984).

From our data (see Tables III and IV) the increase in the frequencies of reciprocal translocation observed in 9 and $10 \mathrm{~Gy}$ is due to an increase in the kind of multivalent configurations. This variability could be dose dependent because the higher doses of ionizing radiations produced six or seven different kinds of multivalent configurations, while the lower ones, two or three (see Table III).

The second group showed an association between all the chemical compounds and the lower doses of ionizing radiation. ADR5, MMC, 0.75 and $1 \mathrm{~Gy}$ are clustered because they all induce the same kind of reciprocal translocations (see Table III). Results obtained from these treatments showed that the two chemicals interacting with DNA through different mechanisms, mainly intercalation (ADR) (Waring, 1970) and alkylation (MMC) (Iyer and Szybalsky, 1963; Schwartz et al., 1963), respectively, induce similar types of chromosomal aberrations as those induced by ionizing radiations. Although the number of cells scored was different (Table IV), the number of "rare multivalent configurations" was similar. This could indicate that presence or absence of these multivalent configurations could be independent of the agent as well as of the doses employed (Table IV). Several explanations have been suggested to explain the mode of action of these compounds. Like other anthracyclines, ADR can intercalate in DNA molecule (Pigram et al., 1972). This feature seems to be an important factor for its genotoxic effect.

Cellular enzymes can convert ADR into free-radical metabolites (Bachur et al., 1979, 1982; Pan and Bachur, 1980), which can bind to DNA or react further to yield DNAdamaging oxygen radicals (Lown and Sim, 1977; Goodman

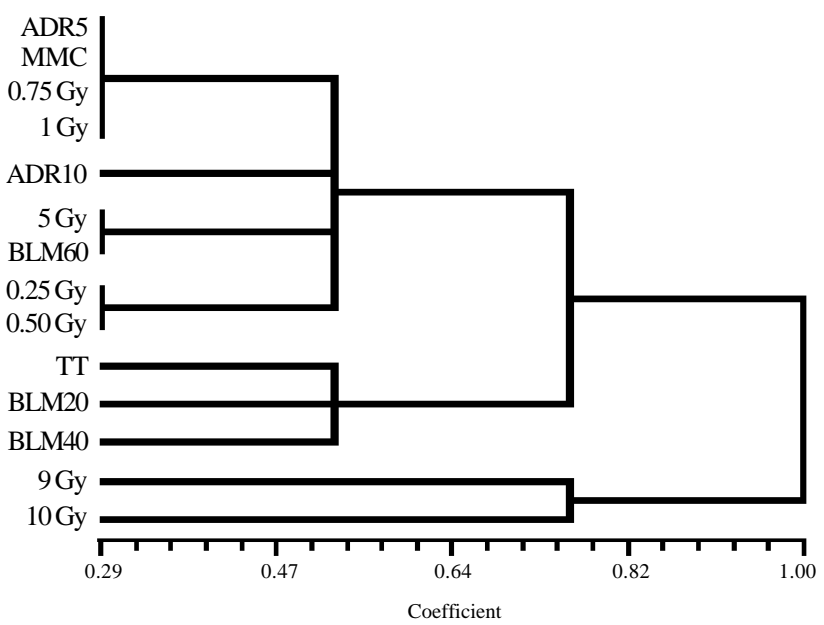

Figure 2 - Consensus dendrogram (majority rule) obtained from the four phenograms presented in Figure 1. The CCC was 0.58333 . See references on Material and Methods, and Table I. 
and Hochstein, 1977; Demopoulos et al., 1980). Other anthracycline actions are membrane disruption and generation of activated oxygen species as well as formation of iron-anthracycline complexes (Hoey et al., 1988).

On the other hand, participation of the hydroxyl radical on the induction of DNA damage by MMC has been reported (Hamana et al., 1985). Futhermore, Dusre et al. (1990) reported that MMC and two analogues produced both free radicals and interstrand cross-links. They suggested that this property may be positively correlated with cytotoxicity, since free radical and interstrand cross-link formation fit cytotoxicity curves for MMC. These results suggest that $\mathrm{MMC}$ can act as a radiomimetic compound.

Results obtained with ADR ( 5 and $10 \mathrm{mg} / \mathrm{kg}$ ) showed a different degree of association, because $5 \mathrm{mg} / \mathrm{kg}$ presented higher affinity with the lowest doses of ionizing radiations

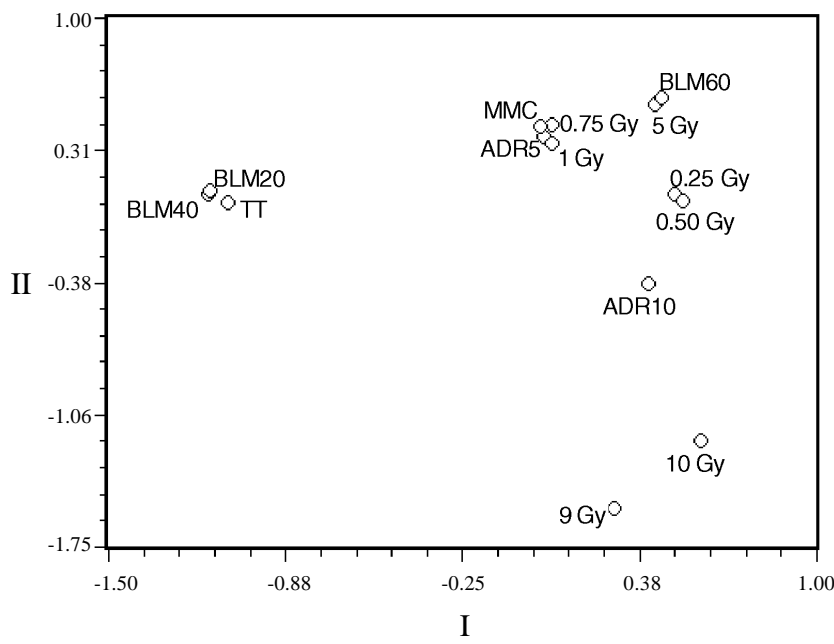

Figure 3 - Multidimensional scaling graph, showing the location of the 14 treatments in a bidimensional graph (axis I-II, $56.88 \%$ of variance). The final "stress" was 0.03893. See references on Material and Methods, and Table I. than that observed for the $10 \mathrm{mg} / \mathrm{kg}$ dose of ADR (Figures 2 and 3 ). This fact suggests a dose-dependent radiomimetic effect of ADR. When male mice were irradiated with $9 \mathrm{~Gy}$ of GR $24 \mathrm{~h}$ after intraperitoneal treatment with two different doses of ADR, only the lower dose $(5 \mathrm{mg} / \mathrm{kg}$ ) presented a potentiating effect, similar to that induced by 1 Gy plus 9 Gy of XR separated by the same lapse (van Buul and Léonard, 1980). The finding of a dose-dependent radiomimetic effect of ADR agrees with results obtained by De Luca et al. (1990a).

BLM is a radiomimetic compound that can induce free radicals and DNA strand breaks (Lown and Sim, 1977; Povirk and Austin, 1991). Then, the association of BLM with different doses of ionizing radiation could be expected. BLM can induce reciprocal translocations in germ cells of mice, and although the frequency is lower than that obtained by ionizing radiations, the kind of multivalent configurations is similar in both cases (van Buul and Gouzdwaard, 1980). Likewise, whereas doses of $60 \mathrm{mg} / \mathrm{kg}$ BLM can be associated with 5 Gy of GR, lower doses ( 20 and $40 \mathrm{mg} / \mathrm{kg}$ ) are not related (Figures 2 and 3). This fact could indicate that the radiomimetic effect of this drug is dose dependent. Supporting this inference, when a dose of $60 \mathrm{mg} / \mathrm{kg}$ BLM was combined with 9 Gy of GR, a potentiating effect was observed (De Luca et al., 1988), and the frequency of reciprocal translocation obtained was similar to that induced by the combined treatment of 1 Gy plus 9 Gy of XR (van Buul and Léonard, 1980).

It has been proposed that results obtained with combined treatments could be explained by assuming that depletion of any kind of spermatogonia is sufficient to modify the chromosomal response of stem cells (van Buul, 1984). This means that the first dose of radiation, after fractionation experiments or chemical treatments $24 \mathrm{~h}$ before irradiation, induces selective cell killing of proliferating spermatogonial cells, triggering the surviving stem cells to enter and active cycle to repopulate the germinal epithelium

Table IV - Multivalent configurations scored for the different treatments.

\begin{tabular}{|c|c|c|c|c|c|c|c|c|c|c|c|}
\hline OTU & $\begin{array}{c}18 \mathrm{II}+ \\
1 \mathrm{CIV}\end{array}$ & $\begin{array}{c}18 \mathrm{II}+ \\
1 \mathrm{RIV}\end{array}$ & $\begin{array}{c}15 \mathrm{II}+ \\
1 \mathrm{CIV}+1 \mathrm{CVI}\end{array}$ & $\begin{array}{c}15 \mathrm{II}+ \\
1 \mathrm{CIV}+1 \mathrm{RVI}\end{array}$ & $\begin{array}{c}17 \mathrm{II}+ \\
1 \mathrm{CVI}\end{array}$ & $\begin{array}{l}16 \mathrm{II}+ \\
2 \mathrm{CIV}\end{array}$ & $\begin{array}{c}16 \mathrm{II}+ \\
1 \mathrm{CVIII}\end{array}$ & $\begin{array}{l}16 \mathrm{II}+ \\
2 \mathrm{RIV}\end{array}$ & $\begin{array}{c}18 \mathrm{II}+ \\
\mathrm{CIII}+1 \mathrm{I}\end{array}$ & $\begin{array}{c}17 \mathrm{II}+ \\
1 \mathrm{RVI}\end{array}$ & $\begin{array}{c}\text { Total cells } \\
\text { scored }\end{array}$ \\
\hline ADR5 & 1 & 1 & 0 & 0 & 0 & 0 & 0 & 0 & 0 & 0 & 1,100 \\
\hline MMC & 5 & 3 & 0 & 0 & 0 & 0 & 0 & 0 & 0 & 0 & 1,069 \\
\hline $0.75 \mathrm{~Gy}$ & 1 & 1 & 0 & 0 & 0 & 0 & 0 & 0 & 0 & 0 & 1,900 \\
\hline $1 \mathrm{~Gy}$ & 1 & 1 & 0 & 0 & 0 & 0 & 0 & 0 & 0 & 0 & 2,000 \\
\hline ADR10 & 1 & 1 & 0 & 0 & 1 & 0 & 0 & 0 & 0 & 0 & 1,200 \\
\hline $5 \mathrm{~Gy}$ & 1 & 1 & 0 & 0 & 0 & 0 & 1 & 0 & 0 & 0 & 995 \\
\hline BLM60 & 1 & 1 & 0 & 0 & 0 & 0 & 1 & 0 & 0 & 0 & 458 \\
\hline 9Gy & 1 & 1 & 1 & 1 & 1 & 1 & 0 & 1 & 0 & 0 & 1,088 \\
\hline $0.25 \mathrm{~Gy}$ & 1 & 1 & 0 & 0 & 0 & 0 & 0 & 0 & 1 & 0 & 2,000 \\
\hline $0.50 \mathrm{~Gy}$ & 1 & 1 & 0 & 0 & 0 & 0 & 0 & 0 & 1 & 0 & 2,500 \\
\hline $10 \mathrm{~Gy}$ & 1 & 1 & 0 & 0 & 1 & 0 & 0 & 1 & 1 & 1 & 2,000 \\
\hline $\mathrm{TT}$ & 1 & 0 & 0 & 0 & 0 & 0 & 0 & 0 & 0 & 0 & 981 \\
\hline BLM20 & 1 & 0 & 0 & 0 & 0 & 0 & 0 & 0 & 0 & 0 & 528 \\
\hline BLM40 & 1 & 0 & 0 & 0 & 0 & 0 & 0 & 0 & 0 & 0 & 560 \\
\hline
\end{tabular}

OUT, Operational toxonomic unit. For other abbreviations see Tables I and II. 
(Cattanach et al., 1976; Cattanach and Crocker, 1980; van Buul, 1983). Accordingly, additive and potentiating effects observed after combined treatments of chemicals and ionizing radiation doses do not depend on the amount of chromosomal damage induced by the chemicals, but rather on the ability of the compound to induce depletion of differentiating or differentiated spermatogonia. Then, two types of effects could be expected: additive, when combined treatments induce a considerable amount of chromosomal damage without killing a great number of cells, and potentiation, when the amount of chromosomal damage induced is so great that the repair mechanisms triggered are not enough to reduce cell mortality. Combined treatments induce extensive cell death and only few surviving cells with a high yield of chromosomal damage can be scored.

However, the subadditive effect observed after combined treatment of MMC plus $4 \mathrm{~Gy}$ (Deknudt and Léonard, 1979), MMC plus 5 Gy (De Luca et al., 1990b) or ADR 5 $\mathrm{mg} / \mathrm{kg}$ (De Luca et al., 1990a) cannot be explained by this assumption. A subadditive effect could be explained assuming involvement of the DNA repair mechanism (De Luca et al., 1988, 1990a; van Buul, 1984). These repair mechanisms can reduce cell mortality in such a way that a higher frequency of more radioresistant cells survive. With a higher dose (ADR 10), the amount of chromosomal damage induced is so great that the repair mechanisms triggered are not enough to reduce cell mortality.

\section{ACKNOWLEDGMENTS}

We thank Dr. Jorge Crisci (LASBE) for his extremely valuable support and critical reading of the manuscript, and Miss Nelly Vittet (LASBE) for her revision of the text. This work was supported by grants from "Consejo Nacional de Investigaciones Científicas y Técnicas" (PID No. 3-050600/88), the "Comisión de Investigaciones Científicas de la Provincia de Buenos Aires" and the "Escuela de Especialización en Ambiente y Patología Ambiental" (National University of La Plata, University of Siena, Italy). This study is part of the "Research Project of the Faculty of Veterinary Sciences, the National University of La Plata", between Japan and Argentina and is supported by JICA (Japan International Cooperation Agency).

\section{RESUMO}

O grau de similaridade entre agentes químicos e físicos quanto a sua capacidade de induzir translocações recíprocas foi analisado por meio de técnicas de análise multivariada. Analisouse o efeito de três diferentes doses de raios gama, quatro doses de raios- $\mathrm{X}$ e diferentes doses de adriamicina, mitomicina $\mathrm{C}$, tiotepa e bleomicina. Os dados foram arranjados em uma matriz básica por 2 métodos: análise de cluster e ordenação. Dois grupos principais foram encontrados, um incluindo doses de 9 e 10 Gy e o outro incluindo as outras doses de radiação ionizante e as substâncias químicas. Vários subgrupos foram encontrados dentro do segundo grupo. Usando dados de presença/ausência, não se encontrou um padrão específico de indução de danos cromossômicos para os agentes físicos e químicos. $\mathrm{O}$ aumento na frequiência de translocação recíproca observado com 9 e 10 Gy deveu-se a um aumento no tipo de configurações multivalentes. Esta variabilidade pode ser dependente da dose. Igualmente, a similaridade observada no segundo grupo entre as substâncias químicas e as doses menores de radiação ionizante também pode ser dependente da dose.

\section{REFERENCES}

Bachur, N.R., Gordon, S.L., Gee, M.V. and Kon, H. (1979). NADPH cytochrome P-450 reductase activation of quinone anticancer agents to free radical. Proc. Natl. Acad. Sci. USA 76: 954-957.

Bachur, N.R., Gee, M.V. and Friedman, R.D. (1982). Nuclear catalyzed antibiotic free radical formation. Cancer Res. 42: 1078-1081.

Cattanach, B.M. and Crocker, A.J.M. (1980). Modified genetic response to X-irradiation of mouse spermatogonial stem cells following fractionated X-rays tretaments: Influence of unequal fraction size and increasing fractionation interval. Mutat. Res. 70: 211-220.

Cattanach, B.M., Heath, C.M. and Tracey, J.M. (1976). Translocation yield from mouse spermatogonial stem cells following fractionated X-ray treatments: Influence of unequal fraction size and increasing fractionation interval. Mutat. Res. 35: 257-268.

Crisci, J.V. and López Armengol, M.F. (1983). Introducción a la teoría y práctica de la taxonomía numérica. Monografía de la O.E.A. (Serie Biológica) 26: 1-32.

Crovello, T.J. (1968). A numerical taxonomic study of the genus Salix section Stichenses. Univ. Calif. Publ. Bot. 44: 1-61.

De Luca, J.C., Dulout, F.N. and Andrieu, J.M. (1988). The induction of reciprocal translocations in mouse germ cells by chemicals and ionizing radiations. I. Dose-response relationships and combined effects of bleomycin with thio-tepa and gamma rays. Mutat. Res. 202: 65-70.

De Luca, J.C., Dulout, F.N., Grillo, C., Tereros, M.C. and Andrieu, J.M. (1990a). The induction of reciprocal translocations in mouse germ cells. II. Combined effects of mitomycin C or thio-tepa with two doses of gamma rays. Mutat. Res. 232: 17-21.

De Luca, J.C., Dulout, F.N., Ulrich, M.A., Furnus, C.C. and Andrieu, J.M. (1990b). The induction of reciprocal translocations in mouse germ cells by chemical and ionizing radiations. III. Differential effect of two doses of adriamycin combined with 5 or 9 Gy of gamma rays. Mutat. Res. 232: 11-16.

Deknudt, G.H. and Léonard, A. (1979). Interactions between ionizing radiations and chemicals in producing chromosomal aberrations in mammals. Mutat. Res. 64: 133 (Abstract).

Demopoulos, H.B., Pietrongiro, B.D., Flamm, E.S. and Seligman, M.L. (1980). The possible role of free radical reactions in carcinogenesis. $J$. Environ. Pathol. Toxicol. 3: 273-303.

Dusre, L.S., Rajagopalan, H.M., Eliot, J.M. and Sinha, B.K. (1990). DNA interstrand cross-link and free radical formation in a human multidrugresistant cell line from mitomycin $\mathrm{C}$ and its analogues. Cancer Res. 50: 648-652.

Goodman, J. and Hochstein, P. (1977). Generation of free radicals and lipid peroxidation by redox cycling of adriamycin and daunomycin. Biochem. Biophys. Res. Commun. 77: 797-803.

Gower, J.C. (1966). Some distance properties of latent root and vector methods used in multivariate analysis. Biometrika 53: 325-338.

Guillie, O.J. and Peto, R. (1969). The detection of complementation map cluster by computer analysis. Genetics 63: 329-347.

Hamana, K., Kawada, K., Sugioka, K., Nakano, M., Tero-Kubota, S. and Ikegami, Y. (1985). DNA strand scission by enzymatically reduced mitomycin C: evidence for participation of the hydroxyl radical in the DNA damage. Biochem. Int. 10: 301-309.

Hoey, B.M., Bulter, J., Lea, J.S. and Sarna, T. (1988). A comparison of free radical properties of several anthracycline anti-tumor and some of their analogues. Free Radical Commun. 5: 169-176.

Iyer, V.N. and Szybalsky, W. (1963). A molecular mechanism of mitomycin action and linkage of complementary DNA strands. Proc. Nat. Acad. Sci. USA 50: 355-362.

Kruskal, J.B. (1964a). Multidimensional scaling by optimizing goodness of fit: a nonmetric hypothesis. Psychometrika 29: 1-27.

Kruskal, J.B. (1964b). Nonmetric multidimensional scaling: a numerical 
method. Psychometrika 29: 115-129.

Leenhoust, H.P. and Chadwick, K.H. (1981). An analytical approach to the induction of translocations in spermatogonia of the mouse. Mutat. Res. 82: 305-321.

Léonard, A. and Deknudt, G.H. (1969). Dose-response relationship for translocations induced by $\mathrm{X}$-irradiation in spermatogonia of mice. Radiat. Res. 40: 276-284.

Lown, J.W. and Sim, S.K. (1977). The mechanism of the bleomycin-induced cleavage of DNA. Biochem. Biophy. Res. Commun. 77: 1150-1157.

Lyon, M.F. and Cox, B.D. (1975). The induction by X-rays of chromosome aberrations in male guinea-pigs, rabbits and golden hamsters. III. Doseresponse relationship after single doses of X-rays to spermatogonia. Mutat. Res. 29: 407-422.

Margus, T. and McMorris, F.R. (1981). Consensus n-trees. Bull. Math. Biol. 43: 239-244.

Pan, S.S. and Bachur, N.R. (1980). Xanthine oxidase catalyzed reductive cleavage of anthracycline antibiotics and free radical formation. Mol. Pharmacol. 17: 95-99.

Pascual, R. and Ortiz Jaureguizar, E. (1990). Evolving climates and mammal faunas in Cenozoic South America. J. Hum. Evol. 19: 12-38.

Pigram, W.J., Fuller, W. and Hamilton, L.D. (1972). Stereochemistry of intercalation: Interaction of daunomycin with DNA. Nat. New Biol. 235: 17-19.

Povirk, L.F. and Austin, M.J.F. (1991). Genotoxicity of bleomycin. Mutat. Res. 257: 127-143.

Rohlf, F.J. (1963). Classification of Aedes by numerical taxonomic method (Diptera: Culicidae). Ann. Entomol. Soc. Am. 56: 798-804.

Rohlf, F.J. (1982). Consensus indices for comparing classifications. Math. Biosci. 59: 131-144.

Rohlf, F.J. (1997). NTSYSpc. Numerical Taxonomy and Multivariate Analysis System. Vol. 2.0. Exeter Software, Setauket, New York, pp. 33.

Sanderson, B.J. and Shield, A.J. (1996). Mutagenic damage to mammalian cells by therapeutic alkylating agents. Mutat. Res. 355: 41-57.

Schwartz, H.C., Sodergen, J.E. and Philips, F.S. (1963). Mitomycin C: chemical and biological studies on alkylation. Science 142: 1181-1183.

Sneath, P.H.A. (1964). New approaches to bacterial taxonomy: use of computers. Ann. Rev. Microbiol. 18: 335-346.

Sneath, P.H.A. (1966). Computer in diagnosis. J. R. Coll. Surg. Edinb. 11 130-132.

Sneath, P.H.A. and Sokal, R.R. (1973). Numerical Taxonomy. Freeman, San Francisco, pp. 573.
Sokal, R.R. and Michener, C.D. (1958). A statistical method for evaluating systematic relationships. Univ. Kans. Sci. Bull. 38: 1409-1438.

Sokal, R.R. and Rohlf, F.J. (1962). The comparison of dendrograms by objective methods. Taxon 11:33-40.

van Buul, P.P.W. (1983). Induction of chromosome aberrations by ionizing radiation in stem spermatogonia of mammals. In: Radiation-Induced Chromosome Damage in Man (Ishihara, T. and Sasaki, M.S., eds.). Alan Liss, New York, pp. 369-400.

van Buul, P.P.W. (1984). Enhanced radiosensitivity for the induction of translocations in mouse stem cell spermatogonia following treatment with cyclophosphamide or adriamycin. Mutat. Res. 128: 207-211.

van Buul, P.P.W. (1991). X-ray induced translocations in premeiotic germ cells of monkeys. Mutat. Res. 251: 31-39.

van Buul, P.P.W. and Gouzdwaard, J.H. (1980). Bleomycin-induced structural chromosomal aberrations in spermatogonia and bone-marrow cells of mice. Mutat. Res. 69: 319-324.

van Buul, P.P.W. and Gouzdwaard, J.H. (1986). Dose-effect relationship for X-ray-induced translocations in spermatogonia of normal and $\mathrm{T} 70 \mathrm{H}$ translocation heterozygous mice. Mutat. Res. 173: 41-48.

van Buul, P.P.W. and Léonard, A. (1980). Evidence of a threshold X-ray dose for sensitizing stem-cell spermatogonia of the mouse to the induction of chromosomal translocations by a second larger one. Mutat. Res. 70: 95-101.

van Buul, P.P.W. and Léonard, A. (1984). Effects of unequally fractionated $\mathrm{X}$-rays exposures on the induction of rearrangements in mouse spermatogonia. Mutat. Res. 127: 65-72.

van Buul, P.P.W. and Seelen, M.C. (1991). The relationship between induced reciprocal translocations and cell killing of rhesus monkey spermatogonial stem cells after combined treatments with follicle-stimulating hormone and X-rays. Mutat. Res. 263: 1-8.

Waring, M.J. (1970). Drugs and DNA: uncoiling of DNA double helix as evidence of intercalation. Humangenetik 9: 234-236.

Williams, W.T., Lambert, J.M. and Lance, G.N. (1966). Multivariated methods plant ecology. V. Similarity analyses and information analysis. $J$. Ecol. 54: 427-445.

Winkler, E.M. and Sokal, R.R. (1987). A phenetic classification of Kenyan tribes and subtribes. Hum. Biol. 59: 121-145.

Wishart, D. and Leach, S.V. (1970). A multivariate analysis of Platonic prose rhythm. Comput. Stud. Hum. Verbal Behav. 3: 90-99.

(Received July 29, 1998) 
